\title{
CYBERBULLYING PERSPEKTIF HUKUM PIDANA ISLAM
}

\author{
Maulida N ur Muhlishotin Dusun M ranten RT .6 RW .3 Baureno \\ nurmukhlishotin@gmail.com Kab.Bojonegoro
}

\begin{abstract}
This article discusses cyberbullying from the perspective of Islamic criminal law. In Law No.19 2016 on Information and electronic Transaction there is no stipulation about cyberbullying. There is, however, stipulation of insult, aspersion, threat and extortion. When looking at the definition of cyberbullying which emphasizes on threat and verbal abuse, this will be punishable based onarticle 29 of the Law. This article stipulates the punishment of maximum 4 (four) year of imprisonment and/or fine of maximum 750.000.000 rupiah. From the perspective of the punishment for offender of cyberbullying as stipulated in the law is suitable with Islamic criminal law.it can be considered as ta'zir with requirement and punishment by the state since ta'zir is not authorized clearly in the Q ur'an and Hadith.
\end{abstract}

Key words: Cyberbullying, Law on Information and electronic transaction, Islamic criminal law

Abstrak: Artikel ini membahas tentang cyberbullying menurut hukum pidana Islam. Dalam Undang-Undang Nomor 19 Tahun 2016 tentang Informasi dan Transaksi Elektroni tid ak terd ap at unsur yang jelas mengenai cyberbullying. $\mathrm{H}$ anya terdapat unsur penghinaan, pencemaran nama baik, pengancaman dan pemerasan. Jika melihat dari definisi cyberbullying yang menitikberatkan pada pengancaman kekerasan secara verbal, sanksi bagi pelaku tind ak kejahatan cyberbullying dikenakan pasal 29 U ndang-Und ang ITE. Pasal ini memp unyai sanksi p idana seb agaimana yang ditentukan dalam Pasal 45B yakni dipidana dengan pidana penjara paling lama 4 (empat) tahun dan/atau denda paling banyak Rp 750.000.000,00 (tujuh ratus lima puluh juta rupiah). Dalam perspektif hukum pidana Islam, hukuman bagi pelaku cyberbullying yang tertuang dalam Undang-Undang Nomor 19 Tahun 2016 tentang Informasi dan Transaksi Elektronik tersebut telah sesuai dengan prinsip-prinsip hukum pidana Islam. Tindak pidana cyberbullying telah memenuhi unsur-unsur yang ada dalam jarîmah ta'zîr yang hukumannya belum ditentukan oleh syara' melainkan diserahkan kepada ulil amri (penguasa), baik penentuannya maupun pelaksanaannya. Karena ta'zîr tid ak ditentukan secara langsung o leh Alquran dan had is, maka ini menjadi kompetensi penguasa setempat.

Kata Kunci: Cyberbullying, Undang-undang tentang Informasi dan Transaksi Elektronik, hukum pidana Islam. 


\section{Pendahuluan}

Perkembangan teknologi dewasa ini semakin meningkat, kebutuhan akan jaringan komputer dibutuhkan oleh siapapun dan kapanpun. Perkembangan alat komunikasi juga mempercepat konektivitas antar manusia dan juga menumbuhkan berbagai bentuk teknologi baru yang membuka ruang baru bagi pasar dan juga investasi bagi perkembangan komputer dan telepon seluler.

Akses teknologi informasi digunakan dalam berbagai hal setiap harinya oleh masyarakat yang mana didukung oleh jaringan internet. Sampai tahun 2009 sekitar 40 juta orang Indonesia menggunakan internet. Angka ini paling tinggi di Asia T enggara. ${ }^{1}$

Indonesia sebagai negara hukum dan negara yang menjunjung tinggi hak kebebasan sesuai dengan pasal 1 Undang-U ndang N omor 9 Tahun 1998 tentang Kemerdekaan M enyampaikan Pendapat Di M uka U mum yang menyatakan bahwa "Kemerdekaan menyampaikan pendapat adalah hak setiap warga negara untuk menyampaikan pikiran dengan lisan, tulisan dan sebagainya secara bebas dan bertanggung jawab sesuai denngan ketentuan peraturan perundang-undangan yang berlaku".

M eskipun kebebasan berpendapat masuk dalam kategori hak dasar yang penting, hak ini adalah hak yang dapat dibatasi. O leh karena itu, dalam setiap sistem HAM (Hak Asasi Manusia) internasional maupun nasional telah diakui jika kemerdekaan berpendapat hanya bisa dibatasi dengang pembatasan yang sangat terbatas dan harus dibuat dengan hatihati dan harus sesuai dengan ketentuan yang berlaku. ${ }^{2} \mathrm{M}$ aka dapat dengan jelas dimaknai bahwa kemerdekaan menyampaikan pendapat harus dengan kemampuan bertanggung jawab, atau tidak seenaknya.

Perbuatan yang dilakukan dalam menyampaikan pendapat di muka umum yang pada akhirnya menimbulkan penghinaan, pelecehan, fitnah, intimidasi yang dijerat dengan beberapa pasal yang telah ada dalam Kitab U ndang-U ndang H ukum Pidana dan Undang-U ndang Informasi dan Transaksi Elektronik. N amun faktanya di Indonesia sendiri penghinaan,

\footnotetext{
${ }^{1}$ Atwar Bajari dan S. Sahala Tua Saragih, Komunikasi Kontekstual; Teori dan Praktik Komunikasi Kontemporer, (Bandung: PT Remaja Rosdakarya 2015), 467.

2 Anggara, et al., Menimbang Ulang Pasal 27 ayat (3) UU ITE dalam Putusan Pengadilan: Pertimbangan Putusan Pengadilan Terkait Penggunaan Pasal 27 ayat (3) UU No 11 Tahun 2008 tentang Informasi dan Transaksi Elektronik di Indonesia, (Jakarta: linstitute for Criminal Justice Reform, 2016), 4.
} 
pelecehan, fitnah dan intimidasi tidak hanya terjadi di muka umum tetapi juga banyak terjadi di dunia teknologi dan informasi.

T eknologi internet juga membawa dampak negatif yang tidak kalah banyak dengan manfaat yang ada, teknologi internet dapat menjadi sarana efektif perbuatan melawan hukum. Kejahatan-kejahatan baru bermunculan seiring dengan berkembangan teknologi informasi dan internet. Kejahatan yang disebut cybercrime atau kejahatan yang melalui jaringan intenet ini mengancam siapapun dengan resiko tertangkap yang sangat minim oleh individu maupun kelompok dengan akibat kerugian yang lebih besar baik untuk masyarakat maupun negara. ${ }^{3}$

Secara umum yang dimaskud kejahatan komputer atau kejahatan di dunia cyber adalah upaya memasuki dan atau menggunakan fasilitas komputer atau jaringan komputer tanpa ijin dan dengan melawan hukum dengan atau tanpa menyebabkan perubahan dan atau kerusakan pada fasilitis komputer yang dimasuki atau digunakan tersebut. ${ }^{4}$

Apa yang saat ini dikenal dengan kejahatan siber (cybercrime) sesungguhnya merupakan berkah negatif dari perkembangan ilmu pengetahuan dan teknologi informasi. Tak heran kalau dikatakan bahwa kejahatan tumbuh dan berkembang mengikuti perkembangan masyarakat, atau dengan kata lain sesungguhnya masyrakatlah yang menyebabkan terjadinya suatu kejahatan. ${ }^{5}$

Untuk mengantisipasi cybercrime, telah lahir suatu rezim hukum baru yang dikenal dengan cyberlaw (hukum siber atau hukum telematika), yaitu hukum yang terkait dengan pemanfaatan teknologi informasi, hukum dunia maya, dan hukum mayantara. ${ }^{6}$ I stilah-istilah tersebut lahir mengingat kejahatan yang dilakukan melalui sistem komputer dan sistem komunikasi, baik dalam lingkup lokal maupun global (internet), dengan memanfaatkan teknologi informasi berbasis sistem komputer yang merupakan sistem elektronik yang dapat dilihat secara virtual.

Kitab U ndang-U ndang H ukum Pidana mengatur penghinaan yang tercantum dalam pasal 310 ayat (1) yang berbunyi:

"Barang siapa dengan sengaja merusak kehormatan atau nama baik seseorang dengan jalan menuduh dia melakukan sesuatu perbuatan

\footnotetext{
${ }^{3}$ Mardani, Bunga Rampai Hukum A ktual, (Jakarta: Ghalia Ind onesia, 2009), 91.

${ }^{4}$ Dikdik M. A rief Mansur dan Elisatris Gultom, Cyber Law; Aspek Hukum Teknologi Informasi, (Bandung: Refika Aditama, 2009), 8.

${ }^{5}$ M ahrus Ali, Dasar-Dasar Hukum Pidana, (Jakarta: Sinar Grafika, 2015), 251.

${ }^{6}$ Mardani, Bunga Rampai..., 93.
} 
dengan maksud yang nyata akan tersiarnya tuduhan itu, dihukum karena menista dengan hukuman penjara selama-lamanya sembilan bulan atau dengan sebanyak-banyaknya empat ribu lima ratus rupiah. ${ }^{77}$

Selain itu, pasal-pasal yang terdapat dalam U ndang-U ndang N o. 19 T ahun 2016 tentang I nformasi dan T ransaksi Elektronik (ITE) juga diharapkan mampu menekan tindak kejahatan yang dilakukan di ruang siber.

Fenomena kejahatan yang bermunculan dewasa ini yaitu cyberbullying, yang akan peneliti titik beratkan dalam penelitian ini. Kejahatan cyberbullying adalah perlakuan kasar yang dilakukan oleh seseorang atau sekelompok orang, menggunakan bantuan alat elektronik yang dilakukan berulang dan terus menerus pada seorang target yang kesulitan membela diri. ${ }^{8}$ Atau dengan kata lain cyberbullying yaitu bentuk intimidasi yang dilakukan seseorang atau lebih untuk memojokkan, menyudutkan, mendiskreditkan orang lain melalui dunia cyber.

Sebagian besar dari kita hanya mengetahui bullying yang dilakukan secara langsung atau bertemu langsung dengan target (sebutan untuk seorang korban) bullying menggunakan kontak fisik maupun verbal. Cyberbullying sama halnya dengan bullying yang terjadi pada umumnya, yaitu sama-sama mengintimidasi ataupun mengganggu orang yang lemah. Yang membedakan antara bullying dan cyberbullying adalah tempat dimana pelaku melakukan intimidasi, ancaman dan pelecehan terhadap target atau korban. Alat perantara yang digunakan pelaku cyberbullying adalah smartphone $e^{9}$ atau komputer yang tersambung dengan jaringan internet. ${ }^{10}$

Di Indonesia kasus cyberbullying mulai bermunculan seiring dengan banyaknya pengguna internet. Contoh kasus yang terjadi pada

\footnotetext{
${ }^{7}$ R. So esilo, Kitab Undang-Undang Hukum Pidana (KUHP) Serta Komentar-Komentarnya Lengkap Pasal Demi Pasal, (Bogor: Politeia, 1995), 225.

8 Machsun Rifauddin, "Fenomena Cyberbullying Pada Remaja (Studi Analisis Media Sosial Faceb o ok", Jurnal IImu Perp ustakaan, Informasi, dan Kearsipan Khizanah Al-Hikmah, N o. 4, (2016), 38.

${ }^{9}$ Smartphone (dalam bahasa Indonesia adalah telepon cerdas) adalah telepon seluler yang mempunyai kemampuan dengan penggunaan dan fungsi yang menyerupai komputer. Bagi beberapa orang, smartphone merupakan telepon yang bekerja menggunakan seluruh perangkat lunak sistem operasi yang menyediakan hubungan standar dan mendasar bagi pengembang aplikasi yang menyajikan fitur canggih seperti surel (surat eletronik), internet dan penyambung VGA.

${ }^{10}$ Yana Choria Utami, "Cyb erbullying di Kalangan Remaja (Studi tentang Korb an Cyberbullying di Kalangan Remaja Surabaya)", Universitas A irlangga, N o. 3, (09, 2014), 3.
} 
bulan M ei T ahun 2016, seorang remaja SM A bernama Sonia D epari yang terlihat sedang berdebat dengan polwan dan mengaku anak jendral BN N Arman D epari di sebuah video yang tersebar luas di internet. Akibatnya para pengguna internet yang melihat kejadian itu kurang senang dengan tindakan Sonia Depari dan menanggapi dengan pem-bully-an yang kurang pas. ${ }^{11}$

Sonia D epari merupakan korban cyberbullying, kehidupan korban dan kerabat akan terganggu akibat cyberbullying yang dilakukan oleh para pengguna internet secara berulang dan berkelanjutan. Korban akan semakin merasa terintimidasi dan ditindas secara tidak langsung. $\mathrm{H}$ al ini akan membuat korban mengalami gangguan psikologis akibat cyberbullying.

Selain itu terdapat pula kasus yang menimpa akun twitter @triomacan2000, dilaporkan karena postingan yang meresahkan dan berisi fitnah serta ancaman yang ditujukan oleh beberapa pihak salah satunya adalah Joko W idodo. Kasus cyberbullying melalui situs jejaring sosial twitter ${ }^{12}$ kemudian dilaporkan ke polisi dan dibawa ke pengadilan untuk proses hukum. Pemilik akun @triomacan2000 dikenai ancaman Pasal 29 jo Pasal 45 ayat (3) U ndang-U ndang Informasi dan Transaksi Elektrronik.

Kasus tersebut merupakan salah satu bentuk cyberbullying yang dimeja hijaukan. Selain daripada itu masih banyak kasus-kasus cyberbullying yang belum termuat oleh media, padahal banyak tulisan maupun gambar yang menyimpang dari etika sehingga menimbulkan bullying namun tidak sampai pada ranah hukum.

I slam mensyariatkan adanya hukuman ('uqûbah) sebagai salah satu tindakan upaya mengurangi kejahatan untuk memelihara ketertiban dan kepentingan masyarakat. H ukum Islam dibagai menjadi bebrapa macam sesuai dengan tindak pidana yang dituangkan dalam syara' ataupun yang tidak terdapat nas hukumnya. D itinjau dari segi ada dan tidak nashnya dalam Alquran dan hadis, hukuman dapat dibagi menjadi dua macam yaitu:

11 Singgih Widiatmoko, "Kasus Cyberbullying Terhadap Remaja Cantik "Sonia Depari"", www.kompasiana.com/singgih_widiatmoko22/kasus-cyber-bullying-terhadap-remaja-cantiksonya-depari_573b2239bb22bd5d098facd9, diakses pada 14 September 2016.

${ }^{12}$ T witter adalah layanan jejaring sosial yang memungkinkan penggunaannya untuk mengirim dan membaca pesan berbasis teks hingga 140 karakter. 
1. H ukuman yang ada nasnya, seperti hudûd, qishâsh, diat dan kafarat, dan.

2. H ukuman yang tidak ada nashnya yaitu ta'zîr.

Di dalam al-Q ur'an Allah swt berfiman:

$\mathrm{H}$ ai orang-orang yang beriman, janganlah sekumpulan orang laki-laki merendahkan kumpulan yang lain, boleh jadi yang ditertawakan itu lebih baik dari mereka. $\mathrm{D}$ an jangan pula sekumpulan perempuan merendahkan kumpulan lainnya, boleh Jadi yang direndahkan itu lebih baik. Dan janganlah suka mencela dirimu sendiri dan jangan memanggil dengan gelaran yang mengandung ejekan. Seburuk-buruk panggilan adalah (panggilan) yang buruk sesudah iman dan barangsiapa yang tidak bertobat, maka mereka itulah orang-orang yang zalim. (Q S. al-H ujurat (49):11).

Dari ayat tersebut dijelaskan bahwa mengintimadasi dan memperolok-olok orang lain adalah perbuatan yang dilarang. $\mathrm{Hal}$ itu seperti apa yang dikaitkan dengan cyberbullying.

Islam sebagai agama yang menjunjung tinggi kehormatan melarang umatnya untuk menghasut, menggunjing, berkata kasar, memanggil dengan julukan tidak baik di hadapan orang, dan perbuatan lain yang menyerang kehormatan dan kemulian manusia. I slam juga mengingatkan untuk menjaga lisan yang telah diberikan oleh Allah untuk berkata baik dan benar agar tidak menimbulkan fitnah dan dosa. Islam juga menempatkan mereka yang berbuat dosa tersebut kedalam golongan orang-orang fasik.

Atas dasar pemikiran yang diuraikan di atas, maka artikel ini membahas tentang analisis hukum pidana Islam terhadap sanksi cyberbullying sebagai kejahatan siber (cybercrime) menurut UU N o. 19 Tahun 2016 tentang ITE".

\section{Pengertian Cyberbullying}

Era globalisasi dan perkembangan teknologi informasi membawa pengaruh terhadap muculnya bentuk kejahatan yang sifatnya baru, seperti cyberbullying. Sebagai salah satu bentuk bullying, aksi kejahatan ini harus ditanggapi dan dicegah. Fenomena cyberbullying merupakan fenomena yang marak terjadi di berbagai negara termasuk Indonesia.

Cyberbullying merupakan perluasan dari bullying, bullying yaitu kekerasan fisik maupun mental yang dilakukan seseorang atau kelompok orang pada seorang atau kelompok orang lainnya sehingga korban merasa 
teraniaya. ${ }^{13}$ Bullying dapat terjadi di mana saja dan divberbagai ranah kehidupan, sosial, politik, budaya, olah raga, pendidikan, dan keluarga. ${ }^{14}$ Cyberbullying sebenarnya tidak lain dari perilaku yang diidentifikasian sebagai bully yang berarti menggangu, menggertak, menghina, dan tindakan pelecehan melalui dunia internet.

Cyberbullying merupakan istilah yang ditambahkan ke dalam kamus OED (O xford English D ictionary) pada tahun 2010. I stilah ini merujuk kepada penggunaan teknologi informasi untuk menggertak orang dengan mengirim atau posting teks yang bersifat mengintimidasi atau mengancam. OED (Oxford English Dictionary) menunjukkan penggunan pertama dari istilah ini di Canberra pada tahun 1998, tetapi istilah ini sudah ada pada sebelumnya di Artikel N ew York Times $1995 .{ }^{15}$

Para ahli mendefinisikan cyberbullying sebagai berikut:

1. Cyberbullying yaitu perlakuan kasar yang dilakukan oleh seseorang atau sekelompok orang, menggunakan bantuan alat elektronik yang dilakukan berulang-ulang dan terus menerus pada seorang target yang kesulitan membela diri.

2. Cyberbullying is the use of technology to intimidate, victimize, or bully an individual or group. Cyberbullying adalah penggunaan teknologi untuk mengintimidasi, menjadikan korban, atau menggangu individu atau sekelompok orang. ${ }^{16}$

Dari pengertian di atas dapat disimpulkan bahwa cyberbulying adalah intimidasi, pelecehan atau perlakuan kasar secara verbal yang dilakukan di dunia maya. Tekanan atau intimidasi baik secara fisik atau verbal dapat menimbulkan depresi. Tetapi, para peneliti menemukan korban aksi cyberbullying mengalami tingkat depresi lebih tinggi dibanding tindakan kekerasan verbal lainnya. Cyberbullying bisa didefinisikan sebagai bentuk pelecehan dan penghinaan yang dilakukan pelaku (bully) kepada korban pada dunia maya atau menggunakan internet misalnya media sosial. Saat bullying dilakukan secara online maka kita tambahkan kata "cyber" didepan kata cyberbullying juga diartikan

\footnotetext{
${ }^{13}$ Yesmil Anwar, Saat M enuai Kejahatan; Sebuah Pendekatan Sosiokultural Kriminologi, Hukum dan HAM, (Bandung: PT Refika Aditama, 2009), 89

${ }^{14} \mathrm{lbid}$.

15 Machsun Rifaudin, "Fenomena Cyberbullying pada Remaja (Studi Analisis Media Sosial Faceb ook", Jurnal IImu Perpustakaan, Informasi, dan Kearsipan Khizanah Al-Hikmah, 4, (2016), 38.

${ }^{16}$ Fathur Rahman, "Analisis M eningkatnya Kejahatan Cyb erbullying dan Hatesp eech M enggunakan Berbagai M edia Sosial dan M etode Pencegahannya", SNIPTEK, (2016), 383.
} 
sebagai bentuk intimidasi yang pelaku lakukan untuk melecehkan korbannya melalui perangkat teknologi. Pelaku ingin melihat seorang terluka, ada banyak cara yang mereka lakukan untuk menyerang korban dengan pesan kejam dan gambar yang mengganggu dan disebarkan untuk mempermalukan korban bagi orang lain yang melihatnya.

Cyberbullying berbentuk kejahatan secara verbal dan mayoritas memakan korban anak-anak. Cyberbullying ada karena penggunaan internet yang dimiliki, pelaku cyberbullying yang menggunakan internet merasa jaringan itu milik mereka, karena itu berhak menentukan aturan penggunaananya, dalam kenyataan mereka bukan pemilik jaringan internet dan tidak akan pernah bisa jadi pemilik. Sebagai pemilik jaringan komunikasi berbasis komputer, dalam mengontrol pesan-pesan yang dikirimkan melalui jaringan miliknya pemilik harus ingat dalam soal kebebasan mengeluarkan pendapat. ${ }^{17} \mathrm{~K}$ arena apabila tidak melihat etika dalam berkomunikasi melalui jaringan internet akan berdampak buruk.

Penggunaan komputer sebagai sebagai sebuah alat untuk melakukan tindak kejahatan dan individu sebagai korban dari tindak kejahatan, cyberbullying dikategorikan sebagai salah satu bentuk cybercrime. Tidak seperti bullying, cyberbullying memungkinkan pelaku untuk menutupi identitasnya melalui komputer. Anonimitas ini membuat pelaku lebih mudah untuk menyerang korban tanpa harus melihat respons fisik korban.

Kejahatan cyberbullying sebagaimana dikemukakan diatas dapat di kategorikan sebagai cybercrime mengingat ciri-ciri khusus sebagai berikut: ${ }^{18}$

1. N on-violence (tanpa kekerasan)

2. Sedikit melibatkan kontak fisik (M inimize of physical contact)

3. M enggunakan peralatan (equipment) dan teknologi

4. Memanfaatkan jaringan telematika (telekomumikasi, media dan informatika) global.

Dengan melihat kejahatan melalui teknologi informasi perbuatan berupa cyberbullying banyak dijumpai di internet. Kejahatan ini perlu dikriminalisasi karenakerugian yang diderita korban dapat lebih serius dan

\footnotetext{
17 Ibid.,

${ }^{18}$ Dikdik M. Arief Mansur dan Elisatris Gultom, Cyber Law: Aspek Hukum Teknologi Informasi, (Band ung: Refika Ad itama, 2009), 27
} 
penyebarannya lebih cepat dibandingkan dengan perbuatan yang dilkukan secara manual.

Bentuk dan macam-macam tindakan cyberbullying sangat beragam, mulai dari mengunggah foto atau membuat postingan yang mempermalukan korban, mengolok-olokan korban hingga mengakses akun jejaring sosial orang lain untuk mengancam korban dan membuat masalah seperti ancaman melalui email dan membuat situs web untuk menyebar fitnah.

\section{Jenis-Jenis $C$ yberbullying}

M enurut W illard, macam-macam jenis cyberbullying, yaitu sebagai berikut: ${ }^{19}$

a) Flamming (terbakar), yaitu mengirimkan pesan teks yang isinya merupakan kata-kata yang penuh amarah dan frontal. Istilah "flame" ini pun merujuk pada kata-kata di pesan yang berapi-api. Flaming secara mudahnya dapat diartikan penghinaan atau komentar kasar terhadap orang lain. Flaming juga dapat berarti lari dari subtansi atau fokus diskusi. Secara lebih luas flaming adalah tindakan provokasi, mengejek, ataupun penghinaan yang menyinggung pengguna lain. ${ }^{20}$ Contoh pertengkaran mengenai kasus prostitusi dalam jaringan yang melibatkan artis berinisial TM dan ASserta mucikari RA. Berawal ketika TM memblokir akun media sosial dan nomor kontak AS yang sedang terkena kasus prostitusi daring (dalam jaringan). AS pun menyindir TM yang dianggap mencari selamat karena tidak mau mengakui bahwa TM juga terlibat kasustersebut. $\mathrm{H}$ al menarik lainnya, seseorang yang diduga mucikari dengan inisial RA pun turut mengomentari status AS. Komentar-komentar lain ikut mengalir dari para pengguna sosial yang kemudian menjadi ajang perang kata-kata dan saling menyindir.

b) $\mathrm{H}$ arassment (gangguan), yaitu pesan-pesan yang berisi gangguan pada e-mail, sms, maupun pesan teks di jejaring sosial dilakukan secara terus menerus. Pelaku harassement akan sering menulis komentar kepada korban yang dimaksudkan untuk menyebabkan kegelisahan dan akan terus mencoba untuk menghasut orang lain untuk melakukan hal yang

${ }^{19}$ Novan Ardy W iyani, Save O ur Children From School Bullying, (Jogjakarta: AR-RUZZ Media, 2012), 14.

20 https:///www.google.com/amps/s/lianurbaiti.wordpress.com, diakses pada tanggal 23 Maret 2016 
sama. Pelaku mungkin masuk ke akun korban kemudian dari akun tersebut pelaku mengirim e-mail cabul atau pesan yang membuat orang sakit hati dan biasanya ditujukan ke keluarga korban, teman, rekan kerja dan atasnya, bahkan bisa juga membuat website dengan menggunakan editan foto seksual dari korban untuk kemudian mengirim foto tersebut ke situs porno amatir.

c) Cybestalking, mengganggu dan mencemarkan nama baik seseorang secara intens sehingga membuat ketakutan besar pada orang tersebut. Contoh akun twitter @triomacan2000 yang beraksi melakukan political bullying ini secara terbuka dan tanpa segan menyudutkan orang-orang tertentu. Akun ini melontarkan berbagai kata intimidasi secara terus menerus terhadap beberapa orang, salah satunya adalah Joko Widodo. Salah satu contoh tweet Trio M acan 2000 tanggal 5 April 2014 berbunyi: "mbak wirda, sorry banget bukan gua yang memulai, tapi Jokowi manusia sampah yang memulai semua...".

d) Denigration (pencemaran nama baik), yaitu proses mengumbar keburukan seseorang di internet dengan maksud merusak reputasi dan nama baik orang tersebut. Seperti Beberapa kasus bahkan membuat laman khusus di media sosial untuk mempermalukan seseorang. Sebuah laman di Facebook yang berjudul Say N o to K dengan jumlah 336.003 like atau suka dibuat untuk mempermalukan citra penyanyi $\mathrm{K}$. Laman ini khusus memposting berita-berita negatif tentang $\mathrm{K}$ disertai komentar-komentar kejam dari para anggotanya. ${ }^{21}$

e) Impersonation (peniruan), berpura-pura menjadi orang lain dan mengirimkan pesan-pesan atau status yang tidak baik. Pada $M$ aret 2016, artis MR melaporkan gugatan terhadap akun Facebook yang mencatut namanya untuk berjualan tas bermerek mahal. M R yang mengaku sudah tidak membuka akun Facebooknya sejak tahun 2010 ini merasa nama baiknya tercemar karena akun palsu menipu para pelanggan dan melarikan uang pembayaran tanpa mengirimkan tas yang dijual.

f) O uting dan trickery, yaitu outing menyebarkan rahasia orang lain, atau foto-foto pribadi orang lain. Sedangkan trickey adalah tipu daya, membujuk seseorang dengan tipu daya agar mendapatkan rahasia atau foto pribadi orang tersebut. ${ }^{22}$

\footnotetext{
${ }^{21} \mathrm{https}$ ///www.faceb ook.com/sayno2kd/?fref=t, diakses pada tanggal 09 Juni 2017.

22 https://www.facebook.com, diakses pada 26 M ei 2017.
} 
g) Exclusion (pengeluaran), yaitu secara sengaja dan kejam mengeluarkan seseorang dari grup online. Kasus ini banyak terjadi di kalangan masyarakat umum berupa peer-group atau kelompok pertemanan. $\mathrm{Di}$ Facebook misalnya, muncul sebuah laman yang mengucilkan seseorang berinisial W ASP dari kelompok berteman. Laman itu bernama WSAP Pelacur Facebook Harus Dikucilkan yang disukai oleh 11 akun Facebook.

Dari beberapa bentuk cyberbullying yang telah dijelaskan di atas, bahwa cyberbullying menitikberatkan kepada kekerasan secara verbal secara tidak langsung yang akan berdampak kepada kondisi emosional atau psikis dari korbannya.

\section{Subjek dan 0 bjek Kejahatan Cyberbullying}

Kejahatan pada dasarnya tumbuh dan berkembang dalam masyarakat, tidak ada kejahatan tanpa masyarakat mempunyai penjahat sesuai dengan jasanya. ${ }^{23}$ Oleh karena itu, kejahatan cyberbullying ada karena banyaknya masyarakat yang menggunakan internet untuk berkominkasi setiap harinya.

Cyberbullying dalam dunia mayantara berpengaruh besar pada kehidupan remaja. Para ahli menyatakan tidak ada jalan keluar dalam cyberbullying (no escape), juga menyatakan para remaja enggan memberitahu orang tua mereka mengenai insiden-insiden online yang terjadi pada mereka disebabkan mereka tidak mau orang tua membatasi keinginan untuk menggunakan internet. O leh karena itu, cyberbullying bisa menjadi beban bagi para remaja karena dapat terjadi waktu yang lama. ${ }^{24}$

Tindakan cyberbullying pada dunia maya tidak mengarah kepada perempuan saja atau laki-laki saja, dengan kata lain cyberbullying tidak mengenal jenis kelamin (gender). ${ }^{25}$

Cyberbullying terdiri dari dua individu yang terlibat, yaitu: ${ }^{26}$

a. pelaku (the bully), adalah seseorang yang secara langsung melakukan agresi baik fisik, verbal, atau psikologis kepada orang lain pada media cyber. Pelaku adalah subjek.

\footnotetext{
${ }^{23}$ Budi Suhariyanto, Tindak Pidana Informasi..., 21

${ }^{24}$ M uhammad Alam Akbar dan Prahastiwi Utari, "Cyb erbullying Pada Media Sosial", Progam Studi IImu Komunikasi FISIP Universitas Seb elas Maret, 2.

${ }^{25}$ lbid., 3

${ }^{26}$ Ibid., 9
} 
b. korban (the victim), adalah seseorang yang menjadi sasaran atau target dari penindasan yang dilakukan oleh pelaku. Korban adalah objek dari cyberbullying.

Berbeda dengan pelaku bullying konvensional, di mana pelaku dapat berupa subjek tunggal yang melakukan agresi terhadap korban, pada kejahatan mayantara pelaku dapat dicirikan menjadi dua, yaitu:

a. pelaku utama, adalah seseorang yang memicu maupun memulai pertama kali penindasan terhadap seseorang. Pelaku utama dapat dilihat pada bentuk postingan yang menjadi pemicu utama baik berupa status maupun kiriman gambar yang bertujuan mengejek atau menghina, merendahkan, menyebarkan gosip atau rumor, mengancam maupun menghancurkan relasi.

b. Pelaku pembantu, apabila orang tersebut ikut berperan dalam mengirimkan pesan berunsur cyberbullying pada tautan, status maupun gambar yang diberikan pelaku utama ditujukan untuk objek sasaran yaitu korban. Pelaku pembantu menjadi representasi wujud cyberbullying yang nyata dimana mayoritas serangan terhadap korban dilakukan oleh pelaku pembantu. D alam beberapa kasus, pelaku utama juga dapat berperan menjadi pelaku pembantu, yaitu turut menyerang korban dengan terus mengirimkan pesan cyberbullying pada tautan yang dikirimkanya sendiri.

Dalam cyberbullying, korban adalah seseorang yang menjadi sasaran atau target dari penindasan yang dilakukan oleh pelaku. Pada penelitian yang dilakukan oleh Budi Setiawan (2011) berjudul "D ealing with Cyberbullies", pemicu korban cyberbullying pada anak-anak atau remaja adalah mereka yang sering diejek dan dipermalukan karena penampilan mereka, warna kulit, keluarga mereka, atau cara mereka bertingkah laku di sekolah. Namun bisa juga si korban cyberbullying justru adalah anak yang populer, pintar dan juga menonjol di sekolah sehingga membuat iri teman sebayanya.

Berbeda dengan pelaku yang memiliki pelaku utama dan pelaku pembantu, pada kasus cyberbullying yang diteliti korban adalah subjek tunggal atau perseorangan.

Ranny Rastati dalam jurnal penelitiannya mengemukakan bahwa cyberbullying selain ditujukan kepada individu, ditemukan pula tiga 
objek, yaitu terhadap lokasi, keagamaan, dan isntitusi atau profesi. ${ }^{27}$ M enurut Ranny Rastati kasus cyberbullying di Indonesia cukup tinggi, sebagaimana temuan dari penelitian yang dilakukan oleh Kementerian Komunikasi dan Informatika bersama U N ICEF pada tahun 2011 hingg 2012. Penelitian tersebut melibatkan 400 anak dan remaja pada rentang usia 10 hingga 19 tahun yang berada di 11 provinsi di Indonesia. $\mathrm{H}$ asil riser menunjukkan bahwa 13\% menyatakan mengalami cyberbullying dalam bentuk hinaan, ancaman, dan dipermalukan di media sosial dan pesan teks. Tidak hanya itu, 9\% menyatakan pernah mengirim pesan berupa hinaan dan kemarahan melalui media sosial dan 14\% melalui pesan teks. Jumlah ini berarti 13 dari 100 responden merupakan pelaku cyberbullying. Cyberbullying bisa menimpa siapa saja dan tidak memandang profesi seseorang. Kejahatan ini bisa terjadi di kalangan selebritas, kalangan pelajar, politikus, bahkan institusi pemerintahan. ${ }^{28}$

\section{M edia C yberbullying}

Dengan adanya media internet yang memiliki berbagai bentuk variasi progam dalam berkomunikasi misalnya, email, blog, twitter dan yang saat ini sangat populer adalah facebook, dapat digunakan sebagai sarana kejahatan pemerasan dan/atau pengancaman. Sebab di internet yang berdimensi dunia maya tidaklah dengan mudah dapat mengidentifikasikan identitas para pihak-pihak yang berhubungan di media ini karena identitas di alam virtual ini sangat mudah untuk dimanipulasi. O leh karena itu, berbeda dengan dunia nyata yang lebih mudah melacak kebenaran identitas seseorang. ${ }^{29}$

M edia yang biasa digunakan dalam cyberbullying adalah sebagai berikut: ${ }^{30}$

\section{a. Instant M essage (I M )}

Instant Message (IM) ini meliputi email dan akun tertentu di internet yang memungkinkan penggunanya mengirimkan pesan atau teks ke pengirim lainnya yang memiliki ID website tersebut.

\footnotetext{
${ }^{27}$ Ranny Rastati, "Bentuk Perundungan Siber di M ed ia Sosial dan Pencegahannya bagi Korban dan Pelaku", Jurnal Sosioteknologi, No. 2, Vol. 15, (A gustus 2016), 180.

${ }^{28} \mathrm{Ibid}$., 170

${ }^{29}$ Budi Suhariyatno, Tindak Pidana Teknologi Informasi (cybercrime); Urgensi Pengaturan dan Celah Hukumnya, (Jakarta: Raja Grafindo Persada, 2014),122.

${ }^{30}$ Darly Albert Reppy, "Cyber-Bullying sebagai Suatu Kejahatan Teknologi ditinjau dari UndangUndang Nomor 11 Tahun 2008 tentang Informasi dan T ransaksi Elektronik", Lex Privatium, Vol. IV, No. 7, (Agustus, 2016), 64
} 


\section{b. Chatroom}

Chatroom merupakan salah satu fasilitas website tertentu, di mana pengguna yang memilik ID disana dapat bergabung dalam satu kelompok chatting. Disini pelaku cyberbullying dapat mengirimkan kata-kata gertakan di mana orang lain dalam group chatting tersebut dapat membaca dengan mudah, dan korban merasa tersudutkan.

c. Trash Polling Site

Beberapa pelaku cyberbullying membuat polling tertentu dengan tema yang diniatkan untuk merusak reputasi seseorang.

d. Blog

Blog merupakan webiste pribadi yang biasa dijadikan buku harian atau diary. Di sini pelaku cyberbullying bebas memposting apa saja termasuk konten yang mengintimidasi seseorang.

e. Bluetooth Bullying

Praktiknya dengan mengirimkan gambar atau pesan yang mengganggu kepada seseorang melalui koneksi bluetooth yang sedang aktif.

\section{f. Sistus J ejaring Sosial}

Situs jejaring sosial yang berisi banyak fitur disalahgunakan pelaku cyberbullying dengan memposting status, komentar, foto, dan lain-lain yang mengganggu, mengintimidasi, menyinggung, dan merusak citra seseorang.

g. Game O nline

Cyberbullying juga banyak ditemukan pada game online. Cyberbullying dapat terjadi pada software game di komputer dengan koneksi internet seperti nintendo, xbox 360, dan playstation. Cyberbullying ini dilakukan pada pemain yang kalah atau pemain baru dan muda.

\section{h. Telepon Seluler}

Telelpon seluler merupakan alat yang sering digunakan oleh cyberbullying dalam menjalankan aksinya, fitur yang digunakan dalam mengintimidasi adalah mengirimkan pesan teks atau SM S (Short M essage Servise), gambar, ataupun vide yang mengganggu korban.

Dalam CMC, teks dan gambar menjadi satu-satunya sarana komunikasi. M edia komputer beserta aplikasi di dalamnya dapat dimanfaatkan untuk menyampaikan tujuan dan kepentingan dari pihak pemberi pesannya. Cyberbullying berupa hinaan, ejekan, pelecehan, dan 
ancaman dilakukan melalui pesan teks. Teks seolah-olah menjadi sebuah bahasa lisan yang disampaikan dalam komunikasi tatap muka dan dapat dimaknai secara beragam.

Seperti pada kasus cyberbullying jenis harassement yang menimpa Farhat Abbas, pengacara kondang ini bermasalah dengan hukum dan terancam masuk penjara karena telah menghina wakil gubernur DKI J akarta Basuki Thahaya Purnama atau Ahok melaui media sosial twitter. Farhat mempermasalahkan penjualan plat mobil pribadi B 2 DKI yang dijual oleh polisi kepada orang umum. Berikut kicauan Farhat Abbas di twitter:

“@farhatabbaslaw: Ahok sana sini plat pribadi B 2 D KI dijual polisi ke orang umum katanya! D asar Ahok plat aja diributin! A papun platnya tetap Cina!"

Kicauan tersebut pun menuai protes protes keras dari sejumlah warga yang notabendya berasal dari kelompok etnis tertentu karena melanggar U U ITE tentang harassement. Farhat pun sudah dilaporkan ke Polda M etro J aya atas dugaan pelanggaran UU N 0. 40 T ahun 2008 pasal 4 dan 16 tentang penghapusan diskriminasi etnis dan ras dan UU ITE pasal 27 ayat 2 oleh Ketua Persatuan I slam Tionghoa Indonesia (PITI), pada Kamis 10 Januari 2013. ${ }^{31}$

\section{C ontoh Kasus $C$ yberbullying}

Contoh kasus cyberbullying yang terjadi akhir ini adalah kasus yang menimpa remaja bernama Sonia D epari pada tahun 2016, pelajar SM A yang karena perbuatannya yang mengaku anak Jendral di hadapan polisi wanita yang hendak menilangnya. Aksinya direkam oleh seseorang dan disebarluaskan di media sosial, hingga akhirnya cyberbullying pun terjadi. Sonia D epari dikatakan stres hingga tidak berani keluar rumah, bahkan ayahnya tertekan melihat pemberitaan dan komentar tentang anaknya hingga mengalami serangan jantung dan tidak tertolong nyawanya. ${ }^{32}$

Selain itu, kasus cyberbullying yang dilakukan oleh akun twitter @triomacan2000 yang beraksi melakukan political bullying ini secara terbuka dan tanpa segan menyudutkan orang-orang tertentu. Akun ini

\footnotetext{
${ }^{31} \mathrm{http}: / /$ megapolitan.kompas.com/read/2013/01/22433393/Kaum.M uslim.T ionghoa.Lap orkan.Far hat.Abbas.ke.Polisi, diakses tanggal $20 \mathrm{M}$ aret 2017.

32 Singgih Widiatmoko, "Kasus Cyberbullying terhadap Remaja Cantik "Sonia Depari"", www.kompasiana.com/singgih_wid iatmoko22/kasus-cyb er-bullying-terhadap -remaja-cantiksonya-depari_573b2239bb22bd5d098facd9, diakses pada 14 September 2016.
} 
melontarkan berbagai kata intimidasi secara terus menerus terhadap beberapa orang, salah satunya adalah Joko Widodo. Salah satu contoh tweet Trio M acan 2000 tanggal 5 A pril 2014 berbunyi: "mbak W irda, sorry banget bukan gua yang memulai, tapi Jokowi manusia sampah yang memulai semua...". Sebagian unggahan akun ini berkali-kali menyebut J oko W idodo pembohong, dan dianggap tidak layak bagi warga Jakarta, jongos mafia cina. Seperti "@triomacan2000: Budak mafia cina "@budi254: @triomacan2000 awas bahaya sekali jika percaya Jokowi"33 dalam isi pesan (tweet) akun @triomacan2000.34

Akun @triomacan2000 akhirnya dijerat dengan Pasal 29 jo Pasal 45 ayat (3) U ndang-U ndang Informasi dan Transasksi Elektronik.

\section{C yberbullying M enurut U ndang-U ndang N o 19 T ahun 2016 tentang Informasi dan Transaksi Elektronik}

Sebagai masyarakat informasi dunia, Indonesia mutlak berperan serta secara aktif dalam berbagai aspek pergaulan dunia internasional. Salah satu aspek yang saat ini tengah dihadapi dunia internasional adalah pemberantasan terhadap cybercrime. $M$ engingat karakteristik cybercrime yang bersifat menggunakan teknologi tinggi sebagai media, maka kebijakan kriminilasasi dibidang teknologi informasi harus memperhatikan perkembangan upaya penanggulangan cybercrime, baik regional maupun internasional dalam rangka harmonisasi dan uniformitas pengaturan cybercrime.

Dengan dikeluarkan dan diberlakukannya pengaturan U ndangUndang Nomor 19 Tahun 2016 Tentang Perubahan atas UndangUndang Nomor 11 Tahun 2008 Tentang Informasi dan Transaksi Elektronik, maka pengelolahan, penggunaan dan pemanfaatan informasi dan transaksi elektronik harus terus dikembangkan melalui infrastuktur hukum dan pengaturannya sehingga pemanfaatannya dengan memperhatikan nilai-nilai agama, sosial dan budaya masyarakat Indonesia, serta untuk menjaga, memelihara dan memperkukuh persatuan dan kesatuan nasional berdasarkan peraturan perundang-undangan demi kepentingan nasional. ${ }^{35}$

\footnotetext{
${ }^{33}$ Twiitter.com/suara Reformasi @triomacan2000

${ }^{34}$ Christiany Juditha, (Cyberstalking Di Twitter @Triomacan2000 Pada Pemilu 2014), Jurnal Penelitian Komunikasi, Vol. 18 No.1, Juli, 2015, 20.

${ }^{35}$ Niniek Suparni, Cyberspace prob lematika dan Antisipasi Pengaturannya, (Jakarta: Sinar Grafika, 2009), 112.
} 
Sebelum Undang-undang Informasi dan Transaksi Elektronik diberlakukan, Kitab Undang-Undang Hukum Pidana (KUHP) telah mengatur hubungan-hubungan hukum tentang kejahatan yang berkaitan dengan komputer (computer crime) yang kemudian berkembang menjadi cybercrime. Ada dua pendapat yang berkembang sejalan dalam menangani kasus kejahatan yang berhubungan dengan komputer yang secara tidak langsung juga berkaitan dengan masalah cybercrime, yaitu: ${ }^{36}$

1. KUHP (Kitab Undang-U ndang H ukum Pidana) mampu menangani kejahatan dibidang komputer (computer crime). M ardjono Reksodiputro kriminolog dari U niversitas Indonesia yang menyatakan bahwa kejahatan komputer sebenarnya bukanlah kejahatan baru dan masih terjangkau oleh KU H P untuk menanganinya. Pengaturan untuk menangani kejahatan komputer sebaiknya diintegrasikan ke dalam KU H P dan bukan ke dalam U ndang-U ndang tersendiri.

2. Kejahatan yang berhubungan dengan komputer (cybercrime) memerlukan ketentuan khusus dalam KUH P atau Undang-Undang tersendiri yang mengatur tindak pidana dibidang komputer.

a) Sahetapy berpendapat bahwa hukum pidana yang ada tidak siap menghadapi kejahatan komputer, karena tidak segampang itu menganggap kejahatan komputer berupa pencurian data sebagai suatu pencurian.

b) J. Sudama Sastroandjojo, menghendaki perlunya ketentuan baru yang mengatur permasalahan tindak pidana komputer. Tindak pidana komputer haruslah ditangani secara khusus, karena caracaranya, lingkungan, waktu, dan letak dalam melakukan kejahatan komputer adalah berbeda dengan tindak pidana lain.

Berdasarkan kenyataan pro kontra mengenai diperlakukannya U ndang-U ndang khusus mengenai cybercrime di atas kemudian berakhir dengan diundangkannya U ndang-Undang Nomor 11 Tahun 2008 tentang Informasi dan Transaksi Elektronik (UU ITE), yaitu UndangU ndang pertama di bidang T eknologi Informasi dan T ransaksi Elektronik sebagai produk legislasi yang sangat dibutuhkan dan telah menjadi pionir yang meletakkan dasar pengaturan di bidang pemanfaatan Teknologi Informasi dan Transaksi Elektronik. ${ }^{37}$

\footnotetext{
${ }^{36}$ Budi Suhariyanto, Tindak Pidana Teknologi Informasi (Cybercrime); Urgensi Pengaturan dan Celah Hukumnya, (Jakarta: RajaG rafind o, 2014), 47.

${ }^{37}$ Undang-Undang N omor 19 Tahun 2016 Tentang Informasi dan Transaksi Elektronik
} 
Undang-U ndang N omor 11 Tahun 2008 Tentang Informasi dan Transaksi Elektronik ini kemudian di revisi dan diperbarui menjadi Undang-Undang Nomor 19 Tahun 2016 tentang Informasi dan Transaksi Elektronik. Karena sejak dilahirkan UU ITE selalu membawa kontroversi, terutama pada bagian kriminalisasi. Salah satu pasal yang menjadi sorotan masyrakat adalah ketentuan pasal 27 ayat 4 UndangU ndang Informasi dan T ransaksi Elektronik, yang berbunyi "Setiap orang dengan sengaja dan tanpa hak mendistribusikan dan/atau mentrasmisikan dan/atau membuat dapat diaksesnya Informasi Elektronik dan/atau Dokumen Elektrik yang memiliki muatan pemerasan dan/atau pengancaman" dan perubahan tersebut atas dasar pertimbangan sebagai berikut: ${ }^{38}$

a. Bahwa untuk menjamin pengakuan serta kehormatan atas hak dan kebebasan orang lain dan untuk memenuhi tuntutan yang adil sesuai dengan pertimbangan keamanan dan ketertiban umum dalam suatu masyarakat yang demokratis perlu dilakukan perubahan terhadap Undang-U ndang Nomor 11 Tahun 2008 tentang Informasi dan Transaksi Elektronik agar terwujud keadilan, ketertiban umum, dan kepastian.

b. Bahwa berdasarkan pertimbangan sebagaimana dimaksud dalam huruf a, perlu membentuk Undang-Undang tentang Perubahan atas Undang-U ndang Nomor 11 Tahun 2008 tentang Informasi dan Transaksi Elektronik.

Dalam Undang-U ndang Nomor 19 Tahun 2016 tentang Perubahan atas Undang-Undang Nomor 11 Tahun 2008 tentang Informasi dan Transaksi Elektronik telah menyediakan kode-kode sosial bersama yang termuat di dalamnya. U ndang-U ndang ini membahas halhal yang terkait dengan informasi melalui elektronik dan perbuatan yang mengganggu. Undang-U ndang Informasi dan Transaksi Elektronik terdapat 10 pasal yang menyimpan ancaman sanksi pidana bagi pelanggarnya, yakni mulai dari pasal 27sampai dengan pasal 37.

Subjek delik yang diakui U ndang-U ndang N omor 19 T ahun 2016 Tentang Perubahan Atas Undang-Undang Nomor 11 Tahun 2008 Tentang Informasi dan Transaksi Elektronik tidak hanya orang perorangan, tapi juga korporasi. Baik orang perorangan maupun korporasi dapat melakukan tindak pidana informasi dan transaksi elektronik yang

${ }^{38}$ Undang-Undang N omor 19 Tahun 2016 T entang Informasi dan Transaksi Elektronik 
jumlahnya sebanyak 19 (sembilan belas) perbuatan yang diatur mulai Pasal 27 hingga Pasal 37 jo Pasal 45 hingga 51, sebagai berikut: ${ }^{39}$

1. Setiap orang dengan sengaja dan tanpa hak mendistribusikan dan/atau mentransmisikan dan/atau membuat dapat diaksesnya informasi elektronik dan/atau dokumen elektronik yang memiliki muatan yang melanggar kesusilaan.

2. Setiap orang dengan sengaja dan tanpa hak mendistribusikan dan/atau mentransmisikan dan/atau membuat dapat diaksesnya informasi elektronik dan/atau dokumen elektronik yang memiliki muatan perjudian.

3. Setiap orang dengan sengaja dan tanpa hak mendistribusikan dan/atau mentransmisikan dan/atau membuat dapat diaksesnya informasi elektronik dan/atau dokumen elektronik yang memiliki muatan penghinaan dan/atau pencemaran nama baik.

4. Setiap orang degan sengaja dan tanpa hak mendistribusikan dan/atau menstransimisikan dan/atau membuat dapat diaksesnya informasi elektronik dan/atau dokumen elektronik yang memiliki muatan pemerasan dan/atau pengancaman.

5. Setiap orang dengan sengaja dan tanpa hak menyebarkan berita bohong dan mnyesatkan yang mengakibatkan kerugian konsumen dalam transaksi elektronik.

6. setiap orang dengan sengaja dan tanpa hak menyebarkan informasi yang ditujukan untuk menimbulkan rasa kebencian atau permusuhan individu dan/atau kelompok masyarakat tertentu berdasarkan atas Suku, Agama, Ras dan Antargolongan (SARA).

7. Setiap orang dengan sengaja dan tanpa hak mengirimkan informasi elektronik dan/atau dokumen elektronik yang berisi ancaman kekerasan atau menakut-nakuti yang ditujukan secara pribadi.

8. Setiap orang dengan sengaja dan tanpa hak atau melawan hukum mengakses komputer dan/atau sistem elektronik milik orang lain dengan cara apa pun.

9. Setiap orang dengan segaja dan tanpa hak melawan hukum mengakses komputer dan/atau sistem elektronik dengan cara apa pun dengan tujuan untuk memperoleh informasi elektronik dan/atau dokumen elektronik dan/atau dokumen elektronik.

39 Hanafi Amrani dan Mahrus Ali, Sistem Pertanggung Jawaban Pidana; Perkembangan dan Penerapan, (Jakarta: Raja Grafind o, 2015), 96. 
10. Setiap orang dengan sengaja dan tanpa hak melawan hukum mengakses komputer dan/atau sistem elektronik dengan cara apa pun dengan melanggar, menerobos, melampaui, atau menjebol sistem pengamanan.

11. Setiap orang dengan sengaja dan tanpa hak atau melawan hukum melakukan intersepsi atau penyadapan atas informasi elektronik dan/atau dokumen el ektronik dalam suatu komputer dan/atau sistem elektronik tertentu milik orang lain.

12. Setiap orang dengan sengaja dan tanpa hak atau melawan hukum melakukan intersepsi atau transmisi informasi elektronik dan/atau dokumen elektronik yang bersifat publik, dari, ke, dan dalam suatu komputer dan/atau sistem elektronik tertentu milik orang lain, baik yang tidak menyebabkan perubahan apa pun maupun yang menyebabkan adanya perubahan, penghilangan, dan/atau penghentian informasi elektronik dan/atau dokumen elektronik yang sedang ditransmisikan.

13. Setiap orang dengan sengaja dan tanpa hak atau melawan hukum dengan cara apa pun mengubah, menambah, mengurangi, melakukan transmisi, merusak, menghilangkan, memindahkan, menyembunyikan suatu informasi elektronik dan/atau dokumen elektronik milik orang lain atau milik publik.

14. Setiap orang dengan sengaja dan tanpa hak atau melawan hukum dengan cara apa pun memindahkan atau mentransfer informasi elektronik dan/atau dokumen elektronik kepada sistem elektronik orang lain yang tidak berhak.

15. Setiap orang dengan sengaja dan hak atau melawan hukum melakukan tindakan apa pun yang berakibat terganggunya sistem elektronik dan/atau mengakibatkan sistem elektronik menjadi tidak bekerja sebagaimana mestinya.

16. Setiap orang dengan sengaja dan tanpa hak atau melawan hukum memproduksi, menjual, mengadakan untuk digunakan, mengimpor, mendistribusikan, menyediakan, atau memiliki:

a) Perangkat keras atau perangkat lunak komputer yang dirancang atau secara khusus dikembangkan untuk memfasilitasi perbuatan sebagaimana dimaksud dalam Pasal 27 sampai Pasal 33;

b) Sandi lewat komputer, kode akses, atau hal sejenis dengan itu ditujukan agar sistem elektronik menjadi dapa diakses dengan 
tujuan memfasilitasi perbuatan sebagaimana dimaksud dalam Pasal 27 sampai dengan Pasal 33.

17. Setiap orang dengan sengaja dan tanpa hak atau melawan hukum melakukan manipulasi, penciptaan, perubahan, penghilangan, pengerusakan informasi elektronik dan/atau dokumen elekronik dengan tujuan agar informasi elektronik dan/atau dokumen elektronik tersebut dianggap seolah-olah data yang auntentik.

Cybercrime, khususnya kejahatan terhadap progam komputer, adalah jenis tindak pidana yang sulit dideteksi. D alam cybercrime masalah pembuktian ini menjadi bagian yang penting, tetapi juga sulit. Pembuktian merupakan syarat memberikan keyakinan pada hakim agar menjatuhkan putusan. Hakim dilarang menjatuhkan putusan sendiri tanpa mendapat keyakinan paling sedikit dua alat bukti sah yang ada. Pasal 183 KUH AP mengatur:40

$\mathrm{H}$ akim tidak boleh menjatuhkan pidana kepada seseorang, kecuali apabila dengan sekurang-kurangnya dua alat bukti yang sah ia memperoleh keyakinan, bahwa suatu saat tindak pidana benar-benar terjadi dan bahwa terdakwalah yang bersalah melakukannya.

D alam pasal 184 KU H AP, telah diberikan pembatasan berbagai alat bukti yang sah yang dapat digunakan sebagai dasar pertimbangan hakim dalam memberikan putusan. D engan telah diberlakukannya U ndangUndang Informasi dan Transaksi Elektronik, maka telah secara sah berlaku pula alat bukti elektronik pada tahap penyidikan, penuntutan dan pemeriksaan di sidang pengadilan, terhadap setiap orang yang melakukan perbuatan hukum Indonesia maupun di luar wilayah hukum Indonesia, yang memiliki akibat hukum Indonesia dan merugikan kepentingan Indonesia (Pasal 2 U ndang-U ndang N omor 11 Tahun 2008). ${ }^{41}$

Dalam Undang-Undang ITE tidak terdapat unsur yang jelas mengenai cyberbullying. $\mathrm{H}$ anya terdapat unsur penghinaan, pencemaran nama baik, pengancaman dan pemerasan. Sedangkan jenis cyberbullying tidak hanya mengandung unsur penghinaan, pencemaran nama baik, pengancaman dan pemerasan saja, tapi menyangkut unsur dari flaming, harassment, impersonation, outing, trickery, exclusion, dan cyberstalking.

\footnotetext{
${ }^{40}$ Kitab Undang-Undang Hukum Pidana \& Kitab Undang-Undang Hukum Acara Pidana, (Bandung: Citra Umbara, 2013), 58.

${ }^{41}$ Nienik Sup arni, Cyb erspace Problematika..., 127.
} 
Jika melihat dari definisi cyberbullying yang menitikberatkan pada pengancaman kekerasan secara verbal. Oleh karena itu hal ini perlu dikriminalisasikan. Secara umum tindak pidana pengancaman diatur dalam Pasal 369 ayat (1) KU H P yang berbunyi:

Barang siapa dengan maksud untuk menguntungkan diri sendiri atau orang lain secara melawan hukum, dengan ancaman akan menista, menista dengan tulisan atau akan mengumumkan suatu rahasia, memaksa seseorang supaya memberikan barang sesuatu yang seluruhnya atau sebagian kepunyaan orang itu atau orang lain, atau supaya membuat utang atau menghapukan piutang, diancam dengan pidana penjara paling lama empat tahun.

Perbuatan dan cara pengancaman yang terdapat dalam Pasal di atas ialah pencemaran dengan ancaman membuka rahasia. Pencemaran maksud dan artinya sama dengan pencemaran dalam Pasal 310 KUH P. Sementara rahasia dalam "ancaman membuka rahasia" adalah keadaan atau kejadian sebenarnya yang menyangkut diri orang yang dipaksa yang disimpan dan tidak boleh diketahui oleh orang lain atau umum, baik ancaman akan mencemarkan atau membuka rahasia, menyebabkan orang tersebut berada dalam suatu keadaan ketidakberdayaan secara psikis, atau dapat menyebabkan perasaan was-was, khawatir dan takut.

Sedangkan tindakan pengancaman yang dilakukan melalui media internet telah diatur oleh pasal 27 ayat (4) yang berbunyi:

"Setiap orang dengan sengaja dan tanpa hak mendistribusikan dan/atau mentransmisikan dan/atau membuat dapat diaksesnya informasi elektronik dan/atau dokumen elektronik yang memiliki muatan pemerasan dan/atau pengancaman."

Pemerasan adalah apa yang dimaksudkan dengan black mail dalam bahasa Inggris. Sementara itu, yang dimaksud dengan pengancaman adalah menyampaikan ancaman terhadap pihak lain. Ancaman harus mengandung janji bahwa orang yang menyampaikan ancaman itu akan melakukan sesuatu yang tidak dikehendaki oleh dan sangat mengkhawatirkan bagi orang yang menerima ancaman apabila sesuatu yang diinginkan oleh orang yang menyampaikan ancaman tersebut tidak terpenuhi oleh pihak yang menerima ancaman. Bila dihubungkan dengan pasal 29 U ndang-U ndang ITE yang secara khusus mengatur mengenai ancaman kekerasan, maka pengancaman yang diatur dalam Pasal 27 ayat (4) ini adalah ancaman yang bukan ancaman kekerasan. Artinya, janji 
pengancaman yang terkandung dalam ancamannya buka berupa "akan melakukan kekerasan" terhadap pihak yang diancam. ${ }^{42}$

\section{Sanksi Cyberbullying menurut U ndang-U ndang N omor 19 Tahun 2016 tentang IT E}

D alam U ndang-U ndang N omor 19 T ahun 2016 tentang I nformasi dan Transaksi Elektroni tidak terdapat unsur yang jelas mengenai cyberbullying. $\mathrm{H}$ anya terdapat unsur penghinaan, pencemaran nama baik, pengancaman dan pemerasan. Jika melihat dari definisi cyberbullying yang menitikberatkan pada pengancaman kekerasan secara verbal, sanksi bagi pelaku tindak kejahatan cyberbullying dikenakan pasal 29 U ndangU ndang ITE. Pasal 29 U ndang-U ndang ITE tersebut menentukan: ${ }^{43}$

"Setiap orang dengan sengaja dan tanpa hak mengirimkan informasi elektronik dan/atau dokumen elektronik yang berisi ancaman kekerasan atau menakut-nakuti yang diajukan secara pribadi."

Dan Pasal ini mempunyai sanksi pidana sebagaimana yang ditentukan dalam Pasal 45B:44

"Setiap orang yang memenuhi unsur sebagaimana dimaksud dalam Pasal 29 dipidana dengan pidana penjara paling lama 4 (empat) tahun dan/atau denda paling banyak Rp 750.000.000,00 (tujuh ratus lima puluh juta rupiah)."

Disebutkan dalam Pasal 29 jo Pasal 45B tersebut bahwa ancaman (termasuk yang mengakibatkan kekerasan fisik, psikis, dan/atau kerugian materiil) tersebut hasruslah ditujukan secara pribadi. Pengancaman yang dimaksud dalam Pasal tersebut juga berupa ancaman membuka rahasia atau mencemar. Apa yang dimaskud pribadi yaitu orang perseorangan (manusia atau natural person) sehingga dengan demikian termasuk korporasi/penjelasan Pasal 29 tidak memberikan keterangan apapun. Tindak pidana ini hanya dapat dipertanggung jawabkan secara pidana kepada pelakunya apabila sasaran atau korban tindak pidana tersebut adalah orang perseorangan karena yang dapat merasa takut adalah manusia.

\section{C yberbullying menurut $\mathrm{H}$ ukum Pidana Islam}

Peradaban di dunia ini telah banyak menciptakan U ndang-U ndang yang bertujuan menjaga kehormatan seseorang. Tetapi semuanya masih

\footnotetext{
${ }^{42}$ Budi Suhariyanto, Tindak Pidana Teknologi Informasi..., 123

${ }^{43} \mathrm{lbid}$.

${ }^{44}$ Ibid., 124
} 
belum mencapai tingkat kesempurnaan karena kurang teliti dalam menyelami seluk beluk jiwa manusia. U ndang-U ndang tersebut kurang menjaga kehormatan dan hak-hak manusia, tidak sebagaimana normanorma etik yang telah disyariatkan dalam Islam.

Cyberbullying merupakan perbuatan yang menggaggu kehormatan manusia, karena bentuk intimidasi dan pengancaman akan pencemaran nama baik. M elihat unsur cyberbullying yang memuat pesan ancaman dan hinaan yang ditujukan oleh seseorang secara terus-menerus.

Suatu kenyataan yang tak dapat dipungkiri lagi, bahwa menjaga kehormatan ini adalah hal yang terpenting untuk menjaga kesatuan dalam tubuh masyarakat. Dan sebaliknya menghina kehormatan atau mencemarkan nama baik akan bisa menimbulkan rasa saling membenci, perpecahan dan hilangnya rasa gotong royong. O leh karena itu, Islam menganggap bahwa setiap hal yang menyentuh kehormatan orang lain termasuk perbuatan dowa yang harus dijauhi oleh orang-orang beriman. D iantara hal-hal yang masuk dalam kategori menghina martabat orang lain adalah menghina orang lain, menuduh dan memberi julukan yang dibenci olehnya, jelek sangkaan, mengintai dan membicarakan perihal orang lain dikala prang tersebut tidak ada. ${ }^{45}$

Menurut al-Ghazali, menghina, mengejek, mencemooh dan menyebutkan aib (terkadang hal itu dilakukan dengan peniruan perbuatan dan perkataan), semua itu adalah perbuatan haram. ${ }^{46}$ Allah swt berfirman:

$\mathrm{H}$ ai orang-orang yang beriman, janganlah suatu kaum mengolok-olokan kaum lain (karena) boleh jadi mereka (yang diolok-olokan) lebih baik dari mereka (yang mengolok-olokan) dan jangan pula wanita-wanita (mengolok-olokan) wanita lain karena boleh jadi wanita-wanita (yang diperolokan) lebih baik dari wanita (yang mengolok-olok). (QS. AlH ujarat: 11).

Berdasarkan ayat di atas, menghina dan mencemar terhadap orang lain, terutama sesama muslim sangatlah dilarang oleh ajaran Islam. Sebab belum tentu orang yang menghina lebih baik daripada yang dihina. 0 rang yang menghina orang lain berarti telah menghina dirinya sendiri, lantaran hal yang seperti itu akan dapat menjatuhkan martabat dan kehormatan seseorang. ${ }^{47}$

\footnotetext{
${ }^{45}$ A bu A hmadi, Dosa dalam Islam, (Jakarta: PT Rineka Cip ta, 1996), 120.

${ }^{46} \mathrm{Al}$-Ghazali, M utiara Ihya' Ulumudd in, (Irwan Kurniawan), (Band ung: Mizan, 1997), 240.

${ }^{47}$ A M udjab Mahali, Pembinaan M oral di M ata AI-Ghazali, (Yogyakarta: BPFE, 1984), 64.
} 
Ayat-ayat tadi, secara tegas dan gamblang melarang kaum muslimin berbuat dosa-dosa sebagai berikut:48

1. M enghina atau mengolok-olok

2. M encela orang lain

3. M enggunakan nama-nama julukan dalam panggil-memanggil antar sesama

4. Jelek prasangka

5. M encari-cari kesalahan orang lain

6. M engumpat.

Sedangkan Abdul Rahman al-M aliki membagi pencemaran menjadi tiga, yaitu:49

1. al-Dzammu yaitu penisbahan sebuah perkara tertentu kepada seseorang berbentuk sindiran halus yang menyebabkan kemarahan dan pelecehan manusia.

2. al-Q adhu yaitu segala sesuatu yang berhubungan dengan reputasi dan harga diri tanpa menisbahkan segala hal tertentu.

3. al-T ahqîr yaitu setiap kata yang bersifat celaan atau mengindikasikan pencelaan atau pelecehan.

\section{Analisis Sanksi Cyberbullying menurut UU No. 19 Tahun 2016 tentang IT E}

Perkembangan teknologi yang pesat didorong dengan kemajuan masyarakat dalam memberikan ekpresinya melalui dunia internet tidak lepas juga dari tindak kejahatan. Pada kenyataan yang ada, tidak terlihat nyata korban dari kejahatan cyber dibandingkan dengan korban dari kejahatan konvensional.

Semua kejahatan pasti menimbulkan korban, suatu perbuatan tertentu dikatakatan jahat karena seseorang dianggap telah menjadi korban, termasuk tentunya korban kejahatan cyber yang meliputi orangperorangan, kelompok orang atau badan yang telah menderita atau korban akibat dari kegiatan ilegal. Kerugian itu bisa secara fisik, psikologis, atau ekonomi.

Seperti halnya dalam kasus cyberbullying, sebuah kejahatan baru yang mucul seiring dengan berkembangnya teknologi ini perlu ditangani dengan serius. Kejahatan seperti ini membahayakan bagi korban karena serangan verbal yang dilakukan oleh pelaku cyberbullying secara terus

\footnotetext{
${ }^{48}$ Abu A hmadi, Dosa dalam Islam..., 121.

${ }^{49}$ A bdurrahman al-M aliki, Sistem Sanksi dalam Islam, (Bogor: Pustaka Thariqul Izzah, 2002), 291.
} 
menerus membuat korban mengalami gangguan psikis, frustasi, enggan bersosialisasi, bahkan bunuh diri.

Cyberbullying dikategorikan sebagai kejahatan siber karena alat dan media yang digunakannya. Yakni memanfaatkan jaringan internet dan alat informasi sepeti komputer dan telepon seluler.

Ketentuan cyberbullying dalam KUHP tidak ada, akan tetapi KU H P mengatur pasal mengenai pengancaman dan penghinaan. Terlepas dari itu Undang-Undang Nomor 19 Tahun 2016 telah mengatur ketentuan mengenai pengancaman dan penghinaan yang dilakukan dengan media elektronik. Ini merupakan pengaturan khusus dari KU H P sebagaimana asas hukum "lex spesialis derogate legi lex generalis".

Kasus Sonia D epari, karena perbuatannya yang mengaku sebagai anak Jendral, Sonia Depari mengalami cyberbullying dan seranganserangan lain yang mengancam, mengusik dan mengolok-ngolok remaja cantik ini. Hingga begitu banyaknya pelaku yang melakukan cyberbullying kepada Sonia Depari ini membuat ayahnya meninggal dunia karena serangan jantung melihat anaknya diperolok-olok dan dihina di internet. Selain kasus Sonia D epari, ada juga kasus cyberbullying yang dibawa hingga ke ranah hukum, yaitu kasus yang menimpa admin twitter @triomacan2000, akun yang setiap harinya memposting dan menyebarkan hinaan serta fitnah ini harus berurusan dengan hukum, dan terancam dengan pasal 29 jo Pasal 45ayat (3) U ndang-U ndang N omor 19 Tahun 2016 tentang Informasi dan T ransaksi Elektronik.

Akun @triomacan2000 setiap harinya memposting gambar dan tulisan melalui twitter ini dikategorikan sebagai cyberbullying jenis cyberstalking.

Cyberbullying dalam Undang-U ndang N omor 19 Tahun 2016 Tentang Informasi dan Transaksi Elektronik memiliki ketentuan yang tertulis dalam Pasal 29 yang berbunyi:

"Setiap orang dengan sengaja dan tanpa hak mengirimkan informasi elektronik dan/atau dokumen elektronik yang berisi ancaman kekerasan atau menakut-nakuti yang ditujukan secara pribadi".

Dan Pasal 29 ini mempunyai sanski pidana sebagaimana yang ditentukan dalam Pasal 45B U ndang-U ndang ITE, yang berbunyi:

"Setiap 0 rang yang memenuhi unsur sebagaimana dimaksud dalam Pasal 29 dipidana penjara paling lama 4 (empat) tahun dan/atau denda paling banyak Rp. 750.000.000,00. (tujuh ratus lima puluh juta)." 
U nsur pada Pasal 29 yaitu ancaman kekerasan dan menakut-nakuti yang mengakibatkan kekerasan fisik, psikis dan/atau kerugian materiil. Pengancaman ini berupa pencemaran dan pada kenyataan yang ada cyberbullyinng yang terjadi memuat unsur pengancaman dan pencemaran. Sanksi hukuman yang diterima oleh pelaku cyberbullying dalam Pasal tersebut relevan dengan apa yang dilakukan. M engingat perbuatan atau kejahatan yang dilakukan oleh pelaku cyberbullying yang membuat korban mengalami tekanan, stres, bahkan bunuh diri.

\section{Analisis H ukum Pidana Islam terhadap Cyberbullying dalam U U N o. 19 T ahun 2016 tentang IT E}

Cyberbullying merupakan suatu tindak kejahatan intimidasi dan mengancam dengan cara memperolok-olok secara terus menerus hingga korban merasa terancam dan tersudutkan. Perbuatan seperti ini dilarang dalam I slam. M engingat I slam mensyariatkan adanya hukuman ('uqūbāh) sebagai salah satu tindakan yang diberikan sebagai pembalasan atas perbuatan yang melanggar ketentuan syariat, dengan tujuan untuk memelihara ketertiban dan kepentingan masyarakat, sekaligus juga untuk melindungi kepentingan individu.

Cyberbullying merupakan tindak pidana atau jarîmah bila dilihat dari unsur-unsur yang harus dipenuhi yaitu:

1. Unsur formil, dalam hal ini cyberbullying tidak ada nas yang mengatur baik dari al-Q ur;an maupun hadis, akan tetapi diatur dalam U ndangUndang Nomor 19 Tahun 2016 tentang Informasi dan Transaksi Elektronik.

D alam hukum pidana Islam, dijelaskan bahwa suatu perbuatan maksiat yang tidak dikenakan had maupun kafarat dikenakan hukuman ta'zîr. O leh karena itu, cyberbullying dikenakan hukuman ta'zîr karena tidak ada nas yang menjelaskan baik di Alquran maupun hadis dan merupakan perbuatan maksiat yang berupa pengancaman dan/atau intimidasi yang merugikan korban.

2. Unsur materiil (al-rukn al-mâddiy), perbuatan yang dilakukan dalam cyberbullying yaitu dengan sengaja mengancam dan mengintimidasi korban dengan mengirim pesan teks atau gambar yang dimuat di dunia maya dengan cara berulang-ulang.

3. U nsur moril (al-rukn 'adabiy), pelaku cyberbullying adalah orang yang cakap hukum (mukalaf) karena mampu memanfaatkan teknologi. 
Jarîmah ta'zîr secara etimologis berarti menolak atau mencegah. Sementara pengertian terminologi ta'zîr adalah bentuk hukuman yang tidak disebutkan ketentuan kadar hukumannya oleh syara' dan menjadi kekuasaan penguasa atau hakim.

Jarîmah ta'zîr apabila dilihat dari hak yang dilanggar dibagi menjadi dua, yaitu jarîmah ta'zîr yang menyinggung hak Allah dan jarîmah ta'zîr yang menyinggung hak individu.

Jarîmah ta'zîr yang menyinggung hak Allah yaitu perbuatan yang berkaitan dengan kemaslahatan umum. Seperti membuat kerusakan di muka bumi, perampokan, penyulundupan, perzinan dan tidak taat pada ulil amri. Sedangkan jarîmah ta'zîr yang menyinggung hak individu yaitu setiap perbuatan yang mengakibatkan kerugian pada orang tertentu atau segala sesuatu yang mengancam kemaslahatan bagi seorang manusia, seperti tidak membayar utang dan penghinaan.

Cyberbullying jika ditinjau dari hak yang dilanggar termasuk jarîmah ta'zîr yang menyinggung hak individu, karena merupakan kejahatan yang mengganggu kemaslahatan seorang manusia. Cyberbullying merupakan kejahatan karena perbuatannya yang merugikan korban baik secarafisik maupun psikis. D alam Islam perbuatan tersebut dikatakan perbuatan maksiat, yaitu meninggalkan perbuatan yang diwajibkan dan melakukan perbuatan yang dilarang.

Adapun cyberbullying jika ditinjau segi dasar hukum (penetapannya), maka kejahatan ini masuk dalam jarîmah ta'zîr, yang baik jenis maupun sanksinya belum ditentukan oleh syara', karena cyberbullying merupakan kejahatan dalam bentuk intimidasi dan pengancaman melalui dunia siber yang tidak akan lepas dari hukuman, sehingga penetapan hukuman kejahatan cyberbullying sepenuhnya diserahkan kepada ulil amri.

Cyberbullying sebagai suatu tindak kejahatan siber (cybercrime) merupakan bentuk kejahatan konvensional yang dilakukan melalui dunia internet. Kejahatan siber masuk dalam ranah jarîmah ta'zîr sebab pada zaman Rasulullah belum ditemukan teknologi komputer dan internet sebagai alat dalam melakukan keajahatan tersebut. M aka dari itu tidak ada satu ayat atau hadis yang menyebutkan secara jelas mengenai eksistensi kejahatansiber seperti kasus cyberbullying.

Tujuan dari ta'zîr atau sanksi ta'zîr adalah bersifat preventif (pencegahan), represif (diharapkan dapat memberi dampak positif bagi 
pelaku), kuratif (diharapkan mampu membawa perbaikan sikap dan perilaku pelaku dikemudian hari) dan edukatif (memberikan pengajaran dan pendidikan sehingga diharapkan dapat memperbaiki pola hidup pelaku). ${ }^{50}$

Adapun macam-macam hukuman ta'zîr cukup beragam, diantaranya adalah:

1. Sanksi ta'zîr yang mengenai badan, hukuman yang terpenting dalam hal ini adalah hukuman mati dan jilid.

2. Sanksi ta'zîr yang berkaitan dengan kemerdekaan seseorang, sanksi yang terpenting dalam hal ini adalah penjara dengan berbagai macamnya dan pengasingan.

3. Ta'zîr yang berkaitan dengan harta, dalam hal ini yang terpenting diantaranya adalah denda, penyitaan/perampasan dan penghancuran barang.

4. Sanksi-sanksi lain yang ditentukan oleh ulil amri demi kemaslahatan umum.

Adapun perbuatan cyberbullying ini termasuk jarîmah dalam ta'zîr, maka hukuman bagi pelaku cyberbullying ditentukan oleh ulil amri (pemerintah). D i Indonesia memiliki U ndang-U ndang nomor 19 Tahun 2016 tentang Informasi dan Transaksi Elektronik.

Dalam hukum pidana Islam, hukuman penjara ini dapat merupakan hukuman pokok dan bisa juga sebagai hukuman tambahan dalam ta'zîr yakni apabila hukuman pokok yang berupa jilid tidak membawa dampak bagi terhukum. ${ }^{51}$

Adapun tentang lamanya penjara dalam hukum pidana Islam para ulama berbeda pendapat. Sebagian ulama berpendapat bahwa lamanya penjara adalah dua atau tiga bulan dan sebagian yang lain berpendapat diserahkan pada hakim. ${ }^{52}$

Sedangkan hukuman penjara seumur hidup adalah hukuman penjara untuk kejahatan-kejahatan yang sangat berbahaya, seperti pembunuhan yang terlepas dari sanksi kisas. Sedangkan hukuman penjara yang dibatasi sampai terhukum beryobat sesungguhnya mengandung pendidikan, sama halnya dengan Lembaga Pemasyarakatan saat ini, yang menerapkan adanya remisi bagi terhukum yang terbukti bahwa telah

\footnotetext{
${ }^{50}$ M. N urul Irfan dan M asyrofah, Fiqih Jinayah, (Jakarta: Amzah, 2013), 146.

${ }^{51}$ M. N urul Irfan dan M asyrofah, Fiqh Jinayah..., 153.

${ }^{52}$ M. N urul Irfan, Hukum Pidana Islam, (Jakarta: Amzah, 2016), 100.
} 
bertobat dan tidak akan mengulangi lagi. Seseorang dianggap bertobat menurut ulama apabila ia melihat tanda-tanda perbaikan perilaku dan tingkahnya, karena tobat dalam hati itu tidak dapat diamat.

Untuk itu sanksi hukuman dalam Pasal 29 jo Pasal 45 ayat (3) Undang-Undang Nomor 19 Tahun 2016 Tentang Informasi dan Transaksi Elektronik telah sesuai dengan hukum pidana Islam, karena dalam hukum pidana Islam. Karena dalam hukum pidana I slam pihak yang berwenang memberlakukan hukuman ta'zîr adalah ulil amri atau pemerintah, dan juga tindak pidana cyberbullying telah memenuhi unsurunsur yang ada dalam jarîmah ta'zîr.

\section{Simpulan}

Sanksi bagi pelaku bagi pelaku cyberbullying menurut UndangUndang nomor 19 Tahun 2016 tentang Informasi dan Transaksi Elektronik diatur dalam Pasal 29 dan dikenakan sanksi pidana sebagaimana yang ditentukan dalam Pasal 45B, karena telah memenuhi unsur-unsurnya yaitu dengan sengaja dan tanpa hak mengirimkan Informasi Elektronik dan/atau D okumen Elektronik yang berisi ancaman kekerasan atau menakut-nakuti yang ditujukan secara pribadi. Sesuai dengan pasal di atas, sanksi bagi pelaku cyberbullying adalah pidana penjara paling lama 4 tahun dan/atau denda paling banyak Rp 750.000 .000 (tujuh ratus lima puluh juta rupiah). D alam pasal 29 jo Pasal 45B Undang-U ndang Nomor 19 Tahun 2016 Tentang Informasi dan Transaksi Elektronik juga disebutkan bahwa ancaman yang dimaksud termasuk yang mengakibatkan kekerasan fisik, psikis, dan/atau kerugiaan materiil.

Tinjauan hukum pidana Islam terhadap cyberbullying sebagai kejahatan siber (cybercrime) menurut U ndang-U ndang nomor 19 T ahun 2016 tentang Informasi dan Transaksi Elektronik yaitu sanksi hukum terhadap cyberbullying dalam Pasal 29 yang mengatur tentang ancaman kekerasan atau menakut-nakuti yang ditujukan secara pribadi dan dikenakan sanksi hukum yang terdapat dalam Pasal 45B yaitu pidana penjara paling lama 4 (empat) tahun dan/atau denda paling banyak $\mathrm{Rp}$ 750.000 .000 (tujuh ratus lima puluh juta rupiah) telah sesuai dengan prinsip-prinsip hukum pidana Islam. Tindak pidana cyberbullying telah memenuhi unsur-unsur yang ada dalam jarîmah ta'zîr yang hukumannya belum ditentukan oleh syarak melainkan diserahkan kepada ulil amri (penguasa), baik penentuannya maupun pelaksanaanya. Karena ta'zîr 
tidak ditentukan secara langsung oleh al-Q ur'an dan hadis, maka ini menjadi kompetensi penguasa setempat. Dalam memutuskan jenis dan ukuran saksi ta'zîr harus tetap memperhatikan petunjuk nas secara teliti karena menyangkut kemaslahatan umum.

\section{D aftar Rujukan}

Ahmadi, Abu. D osa dalam Islam. Jakarta: PT Rineka Cipta, 1996.

Akbar, Muhammad Alam. dan Prahastiwi Utari. "Cyberbullying Pada Media Sosial". Solo: Program Studi IImu Komunikasi FISIP Universitas Sebelas M aret.

Al-Ghazali. Mutiara Ihya' Ulumuddin. Diterjemakan oleh Irwan Kurniawan. Bandung: M izan, 1997.

Ali, M ahrus. D asar-D asar H ukum Pidana. Jakarta: Sinar G rafika, 2015. Al-M aliki, Abdurrahman. Sistem Sanksi dalam Islam. Bogor: Pustaka Thariqul I zzah, 2002.

Amrani, $\mathrm{H}$ anafi. dan M ahrus Ali. Sistem Pertanggung Jawaban Pidana; Perkembangan dan Penerapan. Jakarta: Raja G rafindo, 2015.

Anggara. et al. Menimbang U lang Pasal 27 ayat (3) UU ITE dalam

Putusan Pengadilan: Pertimbangan Putusan Pengadilan Terkait

Penggunaan Pasal 27 ayat (3) UU No 11 Tahun 2008 tentang Informasi dan T ransaksi Elektronik di Indonesia. Jakarta: I institute for C riminal J ustice Reform, 2016.

Bajari, Atwar. dan S. Sahala Tua Saragih. Komunikasi Kontekstual; T eori dan Praktik Komunikasi Kontemporer. Bandung: PT Remaja Rosdakarya 2015.

https:///www.google.com/amps/s/lianurbaiti.wordpress.com, diakses pada tanggal $23 \mathrm{M}$ aret 2016

https://www.facebook.com, diakses pada 26 M ei 2017.

https://www.facebook.com/sayno2kd/?fref=t, diakses pada tanggal 09 J uni 2017.

I rfan, M . N urul. dan M asyrofah. Fiqih Jinayah. Jakarta: Amzah, 2013.

I Ifan, M. N urul. H ukum Pidana I slam. Jakarta: A mzah, 2016.

Juditha, Christiany. Cyberstalking Di Twitter @T riomacan2000 Pada

Pemilu 2014. Jurnal Penelitian Komunikasi. Vol. 18 N 0.1, Juli, 2015.

Kitab Undang-Undang Hukum Pidana \& Kitab Undang-Undang H ukum Acara Pidana. Bandung: Citra U mbara, 2013. 
M ahali, A M udjab. Pembinaan M oral di M ata AI-Ghazali. Yogyakarta: BPFE, 1984.

Mansur, Dikdik M. Arief. dan Elisatris Gultom. Cyber Law: Aspek H ukum Teknologi Informasi. Bandung: R efika Aditama, 2009.

M ardani. Bunga Rampai H ukum Aktual. J akarta: G halia Indonesia, 2009. Rahman, Fathur. "Analisis M eningkatnya Kejahatan Cyberbullying dan $H$ atespeech $M$ enggunakan Berbagai $M$ edia Sosial dan $M$ etode Pencegahannya". SN IPTEK. 2016.

Reppy, D arly Albert. "C yber-Bullying sebagai Suatu K ejahatan T eknologi ditinjau dari Undang-Undang Nomor 11 Tahun 2008 tentang Informasi dan Transaksi Elektronik". Lex Privatium. Vol. IV, N 0. 7, Agustus, 2016.

Rifauddin, M achsun. "Fenomena Cyberbullying Pada Remaja (Studi Analisis Media Sosial Facebook". Jurnal IImu Perpustakaan, Informasi, dan Kearsipan K hizanah Al-H ikmah. N 0. 4, 2016.

Suhariyanto, Budi. Tindak Pidana Teknologi Informasi (Cybercrime); U rgensi Pengaturan dan Celah H ukumnya. Jakarta: RajaG rafindo, 2014.

N iniek Suparni, Cyberspace problematika dan Antisipasi Pengaturannya, (Jakarta: Sinar G rafika, 2009), 112.

N ovan Ardy Wiyani, Save Our Children From School Bullying, (J ogjakarta: AR-RUZZ M edia, 2012), 14.

R. Soesilo, Kitab Undang-Undang Hukum Pidana (KUHP) Serta Komentar-Komentarnya Lengkap Pasal Demi Pasal, (Bogor: Politeia, 1995), .

Ranny Rastati, "Bentuk Perundungan Siber di Media Sosial dan Pencegahannya bagi Korban dan Pelaku", Jurnal Sosioteknologi, N o. 2, Vol. 15, (Agustus 2016), 180.

Singgih Widiatmoko, "Kasus Cyberbullying Terhadap Remaja Cantik "Sonia D epari"",

www.kompasiana.com/singgih_widiatmoko22/kasus_cyberbullying-terhadap-remaja-cantik-sonyadepari_573b2239bb22bd5d098facd9, diakses pada 14 September 2016.

Twiitter.com/suara Reformasi @triomacan2000

Undang-Undang Nomor 19 Tahun 2016 Tentang Informasi dan Transaksi Elektronik 
Yana Choria U tami, "C yberbullying di Kalangan Remaja (Studi tentang Korban Cyberbullying di K alangan Remaja Surabaya)", U niversitas Airlangga, N o. 3, (09, 2014), 3.

Yesmil Anwar, Saat M enuai Kejahatan; Sebuah Pendekatan Sosiokultural Kriminologi, Hukum dan H AM, (Bandung: PT Refika Aditama, 2009), 89

http://megapolitan.kompas.com/read/2013/01/22433393/Kaum.M usli m.T ionghoa.Laporkan.Farhat.Abbas.ke.Polisi, diakses tanggal 20 M aret 2017. 